\title{
PHYTOEXTRACTION OF LEAD FROM POLLUTED SOIL BY Silybum marianum L.
}

\author{
Dr. Ramadhan Omer Hussain \\ Dept. of Horticulture, College of Agriculture, University of Duhok, Kurdistan Region - Iraq
}

(Received: March 24, 2019; Accepted for Publication: May 29, 2019)

\begin{abstract}
The process of remediation soils polluted by heavy metals require huge efforts and economic costs, therefore phytoextraction of heavy metals from these soils is very important, because it is a cost effective and environmentally friend method. This study conducted to estimate lead phytoextraction ability of Milk thistle (Silybum marianum L.) from soil polluted with lead. A pot experiment was conducted on Milk thistle under plastic house conditions at the Department of Horticulture, College of Agriculture, University of Duhok. The plant grown in soil polluted artificially with different concentrations of lead $\left(40,80,160\right.$, and $320 \mathrm{mg}^{-\mathrm{kg}^{-1}}$ soil) and irrigated with tap water. The study lasted about five months from January 2015 to the end of May 2015. At the end of the experiment the biomass of roots and shoots determined. Concentration of lead in roots and shoots also determined. Bioconcentration factor (BCF), translocation factor (TF), bioaccumulation factor (BAF), and removed lead also measured. Plant's biomass decreases as lead concentration in soil increased and the lowest biomass recorded in plants sampled from pots received higher lead. Lead content in shoots and roots of $S$. marianum ranged from (26.06-49.56) and (26.74-44.70) $\mathrm{mg}^{-\mathrm{kg}^{-1}}$ d.wt respectively. Values of (BCF), (BAF), and (TF) ranged from (0.13-1.07), (0.14-1.04) and (0.92-1.20) respectively. The amount of removed lead by each plant ranged from $\left(213.3-285.6 \mu g\right.$. plant $\left.^{-1}\right)$. Milk thistle plants showed a good ability for translocation of absorbed lead from roots to shoots therefore it can be considered a hyperaccumulator plant of lead because TF was more than one.
\end{abstract}

KEYWORDS: Phytoextraction, $\mathrm{Pb}$, Silybum marianum L., bio-accumulation factor (BAF), bioconcentration factor, and Translocation factor.

\section{INTRODUCTION}

$\mathbf{T}$ he pollution of the environment with heavy metals has become a global problem, therefore cleaning the soil from these metals is necessary (Angelova et al., 2018). Remediation of these soils require removal of these toxic heavy metals (Henry, 2000). Although the cleaning of the soils contaminated with heavy metals by conventional methods is very efficient, but they are very expensive, sever labor demanding and cause bad disturbance to soil biota (Pulford and Watson, 2003).

As an alternative to these traditional methods of environment cleaning, phytoextraction strategies have been developed; which is the use of some plants in order to remove heavy metals from the environment and accumulate it in the above ground tissues then removed by harvesting (Meers et al., 2005). Phytoextraction is a promising low cost technique compared with traditional methods (Evangelou et al., 2007). It is in situ methods for removing heavy metals from the soil and water (Fulekar et al., 2009).

Lead it is one of the most important toxic heavy metals that are present naturally in the earth crust (Gabos et al., 2009). But over 200 years ago a considerable amount of these metals have been emitted significantly more than natural sources (Clemens, 2006). These due to many industrials and commercial uses of lead such as in ceramic, medicals, batteries, solders, alloys, and in insecticides also lead used as anti knock in gasoline as tetraethyl lead or as tetramethyl lead (Kumar et al., 1995). The main source of lead pollution in the Iraq are automobiles (Mohamed et al., 2003). Tetraethyl or tetramethyl lead converted to inorganic salts and exhaust out of the engine of automobiles as halides, oxides, sulfates and carbonates (National academy of Science, 1972). Lead halides are easy instant in soil 
solution and more toxic to plants (Zimdahl and Koeppe, 1979).

Lead produced from human activities released into soil, water and air (Fulekar et al., 2009). When soil polluted with lead it can very easily incorporated into food chains (Awofolu, 2005). It enters human body through inhalation and by absorption, lead and other heavy metals are non biodegradable and accumulate in organism's tissues (Ali et al., 2012). Emission of high concentrations of lead affects human health in different ways, such as mental declining and cognitive effects of human (Paz-Alberto et al., 2007). Because lead is continuously used; its accumulation in the environment have been increased dangerously. (Nas and Ali, 2018).

Silybum marianum L. is belong to the family Asteraceae, and it is a biannual or annual plant grown originally in Southern Europe, Asia, North Africa, America and Australia, is now distribute overall the world (Ghafor et al., 2014 and Wianowska and Wiśniewski, 2014). In Iraq and Kurdistan Region milk thistle is a biennial weed plant that completes its live cycle in winter and spring. It consumed fresh; peeled stems and young heads are eaten raw, or mixed with sour materials such as sumac and lemon, also used as animal feed. In some area consumed as dietary supplement because of its benefits for liver health, in cosmetic, production of biofuel (Tournas et al.
2012). In Europe and USA used as nutritional supplements in various forms such as seeds, fresh herb, powder of the herb, oil of seeds and capsules (Andrzejewska et al., 2015). Many studies have shown that Milk thistle is tolerant to heavy metals pollution, it considered a hyperaccumulator plant of lead, and accumulate a considerable amount of cadmium and zinc. The plant can be successfully used in the phytoremediation of heavy metal contaminated soils (Angelova et al., 2018).

The main aim of this study is to evaluate the potential of lead phytoextraction ability of $S$. marianum L. and to estimate the values of lead transported from substrate through roots to shoots.

\section{MATERIALS AND METHODS}

The study was conducted under plastic house conditions during the period January 2015- end of May 2015 at the Department of Horticulture, College of Agriculture, University of Duhok, Kurdistan Region, Iraq.

\section{Preparation substrate}

Surface soil was collected from a depth of $(0-$ 20) $\mathrm{cm}$ from the fields of college of AgricultureUniversity of Duhok. The collected soil was air dried, and clods were crushed, then sieved through a 4-mm sieve. Sieved soil mixed with loam in ratio of (3 loam: 1 soil). The chemical and physical properties of substrate are shown in table (1):

Table (1): Some chemical and physical properties of substrate.

\begin{tabular}{ccl}
\hline Soil parameter & Unit & Value \\
\hline Clay & $\%$ & 69.5 \\
\hline Sand & $\%$ & 11.1 \\
\hline Silt & $\%$ & 19.4 \\
\hline Soil texture & --- & Clay \\
\hline $\mathrm{E} \mathrm{C}$ & $\left(\mathrm{ds} \cdot \mathrm{m}^{-1}\right.$ & 0.462 \\
\hline $\mathrm{pH}$ & --- & 7.4 \\
\hline Moisture & $\%$ & 3.87 \\
\hline Total CaCO & $\%$ & 13.74 \\
\hline Organic matter & $\%$ & 0.95 \\
\hline Total $\mathrm{Pb}$ & $\%$ & 25 \\
\hline
\end{tabular}

\section{Lead addition}

$10 \mathrm{~kg}$ of the mixture (loam+soil) were added to the pots. Four concentrations of lead (40, 80, 160, and $320 \mathrm{mg} . \mathrm{kg}^{-1}$ soil) was applied to pots by dissolving analytically grade $\mathrm{Pb}\left(\mathrm{NO}_{3}\right) 2$. in two litters of distilled deionized water. Because field capacity of the mixture was $20 \%$ it means that we need two litters of water to confirm that all the soil present in the pot had been saturated with the added solution. in addition to control (cont.) which itself contains $25 \mathrm{mg} . \mathrm{kg}^{-1}$ soil of lead, all treatments were replicated five times. 
Pots were placed in the plastic house for a period of one month. During that period, the pots were watered with deionized distilled water. This process was taken to enable added $\mathrm{Pb}\left(\mathrm{NO}_{3}\right) 2$ to reach a steadiest condition (Blaylock et al., 1997).

At the end of the incubation period (beginning of December), the pots were distributed on five blocks, each block contained five experimental units (five treatments; control, 40, 80, 160, and $320 \mathrm{mg}$. kg ${ }^{-1}$ soil). Each experimental unit composed from five pots. Randomized Complete Block Design (RCBD) with five replicates was adapted for the implementation of the experiment.

\section{Source of seeds}

Ten seeds of Sylibum marianum L. were planted in each pot (seeds were collected from the same region in the year prior to experiment). Pots were watered with tap water (specifications of irrigation water are represented in table 2). after full germinations and emergence of real leaf, seedlings were thinned to three plants for each pot. Saucers of $30 \mathrm{~cm}$ diameter were placed under pots to prevent leaching of water from pots. During the period of the experiments plants were irrigated with tap water only. Any weeds or foreign plants were removed immediately after the germination. Also we didn't record any cases of disease or insect infection on plants.

Table (2): Some chemical properties of water used for irrigation

\begin{tabular}{|c|c|c|}
\hline Water characteristics & Unit & Value \\
\hline Turbidity & NTU & 0.1 \\
\hline Color & ---- & Clear \\
\hline $\mathrm{pH}$ & ---- & 7.27 \\
\hline $\mathrm{EC}$ & ds. $m^{-1}$ & 0.792 \\
\hline Total dissolved solids & $\mathrm{mg} \cdot \mathrm{l}^{-1}$ & 506.7 \\
\hline Total alkalinity & $\mathrm{mg} \cdot \mathrm{l}^{-1}$ & 386.0 \\
\hline lead & $\mathrm{mg} . \mathrm{l}^{-1}$ & 0.0062 \\
\hline Calcium & $\mathrm{mg} . \mathrm{l}^{-1}$ & 79.9 \\
\hline Magnesium & $\mathrm{mg} \cdot \mathrm{l}^{-1}$ & 60.0 \\
\hline Chloride & $\mathrm{mg} \cdot \mathrm{l}^{-1}$ & 21.4 \\
\hline
\end{tabular}

\section{Plants uprooting}

The plants were uprooted at the end of April and before flowering. Shoots were cut at soil level, substrate of pots was broken carefully and all roots were collected. Both of roots and shoots gently washed with tap water and then with distilled water, then air dried for two days followed by drying in an oven at $70^{\circ} \mathrm{C}$ for 48 hours. Dry weight of roots and shoots was recorded.

Dry samples of roots and shoot were grinded well and $0.5 \mathrm{~g}$ of each sample was taken and putted in a $100 \mathrm{ml}$ conical flask. Samples were wet digested by a mixture of $\mathrm{HNO}_{3}$ and $\mathrm{HClO}_{4}$ at a ratio (4:2) (Tandon, 1999).

Lead concentration in samples determined by Atomic Absorption Spectrophotometer type (G B $C)$ in the laboratory of researches center in College of Agriculture, University of Duhok.

\section{Analysis of data}

Randomized completely block design (R C B D) was applied (Al-Rawi and Khalaf, 2000). The program Microsoft (S A S 2002) was used for statistical analysis. The differences between means of treatment were tested with Duncan Multiple Range test at 5\% level (Duncan, 1955).

\section{RESULTS AND DISCUSSION}

The dry weight (plant biomass) of $S$. marianum L. (table 3) of control plants differed nonsignificantly from plants treated with $(40 \mathrm{mg} \mathrm{Pb}$. $\mathrm{kg}^{-1}$ soil) but both of them differed significantly from plants sampled from pots treated with $(80$, 160 , and $320 \mathrm{mg} \mathrm{Pb} \mathrm{kg}^{-1}$ soil), also there were no significant differences among last three treatments. Roots biomass decreased spontaneously with the increased lead concentration, but non-significantly. 
The reduction of $S$. marianum L. biomass is due to the various negative effects of lead such as reduction of photosynthesis rate through inhibition of chloroplast formation (Habash et al, 1995); inhibition in transport chain of both photo system 1 and 2 (Sharma and Dubey, 2005). Lead inhibit root hairs formation and lower the permeability of membrane (Mukhopdhyay and Maiti, 2010). Also inactivation of different enzymes throughout binding wit SH- groups have been recirded by (Pinho and Ladeiro, 2012). Mukhopadhyay and Maiti (2010) found that lead bind to the ioncarriers thereby preventing absorption and translocation of other essential metals for plant growth such as $\mathrm{P}, \mathrm{Ca}, \mathrm{Mg}, \mathrm{Zn}, \mathrm{Mn}$, and $\mathrm{Fe}$.

Table (3): Shoots and roots dry weight $\left(\mathrm{g}\right.$. plant $\left.{ }^{-1}\right)$ of S. marianum L.

\begin{tabular}{lll}
\hline Pb levels & Shoots & Roots \\
\hline cont. & $8.22 \mathrm{a}$ & $4.71 \mathrm{a}$ \\
$\mathbf{4 0}$ & $8.34 \mathrm{a}$ & $4.63 \mathrm{a}$ \\
$\mathbf{8 0}$ & $6.58 \mathrm{~b}$ & $4.50 \mathrm{a}$ \\
$\mathbf{1 6 0}$ & $6.42 \mathrm{~b}$ & $4.08 \mathrm{a}$ \\
$\mathbf{3 2 0}$ & $5.50 \mathrm{~b}$ & $4.07 \mathrm{a}$ \\
Mean & 7.01 & 4.40 \\
\hline
\end{tabular}

In each column values with same letter are not significantly different.

Lead content in roots and shoots of $S$. marianum $\mathbf{L}$.

Discovery of heavy metals concentration in plant tissues is a major step in developing phytoremediation process of soils impacted by toxic metals (Angelova, 2013). Lead concentration in shoots and roots of $S$. marianum $\mathrm{L}$. is summarized in table 4 , it can be seen that the higher lead content (49.56 mg. $\mathrm{kg}^{-1}$ d.wt) was measured in plants grown in pots treated with (320 mg. $\mathrm{kg}^{-1}$ soil), which differed non-significantly with treatment (160 mg. kg ${ }^{-1}$ soil), but both of them differed non-significantly from treatments (40 and $80 \mathrm{mg} . \mathrm{kg}^{-1}$ soil) which themselves all different significantly with control but nonsignificantly from each other.

However the higher lead content $(44.70 \mathrm{mg}$. $\mathrm{kg}^{-1}$ d.wt) was recorded in plant roots treated with (320 mg. kg-1 soil) of lead but no significant differences recorded among it and both of (40 and $80 \mathrm{mg}$. $\mathrm{kg}^{-1}$ soil) treatments. Lead content in roots of control plants different significantly from all other treatments but non-significantly with (40 mg. $\mathrm{kg}^{-1}$ soil) treatment. These results are more than $\left(20.5\right.$ and $20.6 \mathrm{mg} \cdot \mathrm{kg}^{-1}$ dwt. $)$ of $\mathrm{Pb}$ respectively in roots and shoots of Silybum marianum found by (Angelova, 2013). Also our results were more than $\left(2.34 \mathrm{mg} \cdot \mathrm{kg}^{-1}\right.$ dwt.) of $\mathrm{Pb}$ in stems of $S$. marianum recorded by (Ghafor et al., 2014). On other hand our results were less than the results of (Del Rio-Celestino, 2006); who found $\left(6211.4 \mathrm{mg} \cdot \mathrm{kg}^{-1} \mathrm{dwt}\right.$.) of $\mathrm{Pb}$ in roots and (735.4 mg.kg ${ }^{-1}$ dwt.) in shoots of $S$. marianum grown in pots contained $500 \mathrm{mg} \cdot \mathrm{kg}^{-1}$ dwt. $\mathrm{Pb}$. Also Sajad et al., (2018) recorded more lead in roots and shoots of Milk thistle (148.0 and 49.33 mg. $\mathrm{kg}^{-1}$ dwt.) respectively.

Duplication of lead concentration in substrate didn't show same manner of lead concentration in Milk thistle tissues, this because lead is one of the heavy metals that dissolve very slowly in the soil (Gabos et al. 2009). 
Table (4): Lead concentration (mg. $\left.\mathrm{kg}^{-1} \mathrm{~d} . \mathrm{wt}\right)$ in roots and shoots of S. marianum L.

\begin{tabular}{ccl}
\hline Pb levels & Shoots & Roots \\
\hline cont. & $26.06 \mathrm{c}$ & $26.74 \mathrm{c}$ \\
\hline $\mathbf{4 0}$ & $33.72 \mathrm{~b}$ & $33.78 \mathrm{bc}$ \\
\hline $\mathbf{8 0}$ & $34.52 \mathrm{~b}$ & $37.56 \mathrm{ab}$ \\
\hline $\mathbf{1 6 0}$ & $44.34 \mathrm{a}$ & $38.38 \mathrm{ab}$ \\
\hline $\mathbf{3 2 0}$ & $49.56 \mathrm{a}$ & $44.7 \mathrm{a}$ \\
\hline Mean & 37.64 & 36.232
\end{tabular}

In each column values with same letter are not significantly different.

Biocncentration (BCF), translocation (TF), and bioaccumulation (BAF) factors

The ability of plants to concentrate heavy metals from soil estimated by the biocncentration factor (BCF) [Pb in roots] / [Pb in soil $]$ which is a ratio between metals concentration in roots and soil (Qu et al., 2011). The absorbed metal must be transported to the above ground parts in order to be easy for harvesting, plants ability for translocation of metals from roots to shoots is measured as translocation factor (TF) $[\boldsymbol{P} \boldsymbol{b}$ in shoot] / [Pb in roots] which is a ratio between metal concentration in shots and roots $(\mathrm{Qu}$ et al., 2011). Another good indicator of phytoextraction is the bioaccumulation factor (BAF) [Pb in shoot] / [Pb in soil], which is the metal content in the plant shoots compared to metal concentration in the substrate (Goswami et al., 2010)

In table (5) we can see significant differences in $\mathrm{BCF}$ among all treatments except between

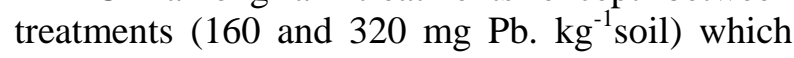

was non-significant. The value of TF of all treatments shows insignificant differences. BAF of control plants and treatment $\left(40 \mathrm{mg} \mathrm{Pb} . \mathrm{kg}^{-}\right.$ ${ }^{1}$ soil) differed significantly from all other treatments.

It is clear that the $\mathrm{BCF}$ and $\mathrm{BAF}$ decreased as lead concentration in the soil increased, because of low lead content in roots and shoots, it can be explained by the fact that the higher lead concentration in the soil does not mean necessarily high lead content in plant tissues (shoots and roots) because of low lead solubility (Gabos et al, 2009).

According to Suchkovaa et al (2010) a hyperaccumulator plant are that plants that transport amount of metal from their roots to their shoots to achieve translocation factor more than 1; in our study the mean translocation factor of all treatments is slightly exceeded 1 therefore $S$. marianum can be considered a $\mathrm{Pb}$ hyperaccumulator plant.

Table (5): BCF, TF, and BAF of $S$. marianum L.

\begin{tabular}{llll}
\hline Pb levels & BCF & TF & BAF \\
\hline Cont. & & & $1.04 \mathrm{a}$ \\
\hline $\mathbf{4 0}$ & $1.07 \mathrm{a}$ & $0.99 \mathrm{a}$ & $0.52 \mathrm{~b}$ \\
\hline $\mathbf{8 0}$ & $0.52 \mathrm{~b}$ & $1.00 \mathrm{a}$ & $0.33 \mathrm{c}$ \\
\hline $\mathbf{1 6 0}$ & $0.36 \mathrm{c}$ & $0.92 \mathrm{a}$ & $0.24 \mathrm{~cd}$ \\
\hline $\mathbf{3 2 0}$ & $0.21 \mathrm{~d}$ & $1.20 \mathrm{a}$ & $0.14 \mathrm{~d}$ \\
\hline Mean & $0.13 \mathrm{~d}$ & $1.12 \mathrm{a}$ & 0.45 \\
\hline
\end{tabular}

In each column values with same letter are not significantly different. 


\section{Removal lead}

Figure (1) shows removal lead by individual plants of $S$. marianum which calculated from the equation [Pb in shoots] $\times$ [plant weight] it can be seen that removal lead by plants in pots treated with (40 and $160 \mathrm{mg} \mathrm{Pb} . \mathrm{kg}^{-1}$ soil) didn't different significantly from each other but significantly from treatments (control; 80 and $320 \mathrm{mg} \mathrm{Pb.} \mathrm{kg}^{-}$ ${ }^{1}$ soil). No significant differences appeared among plants of three treatments. The maximum removed lead $\left(285.66 \mu \mathrm{g}\right.$. plant $\left.^{-1}\right)$ obtained from plants grown in pots polluted with $(160 \mathrm{mg} \mathrm{Pb} . \mathrm{kg}$ ${ }^{1}$ soil).

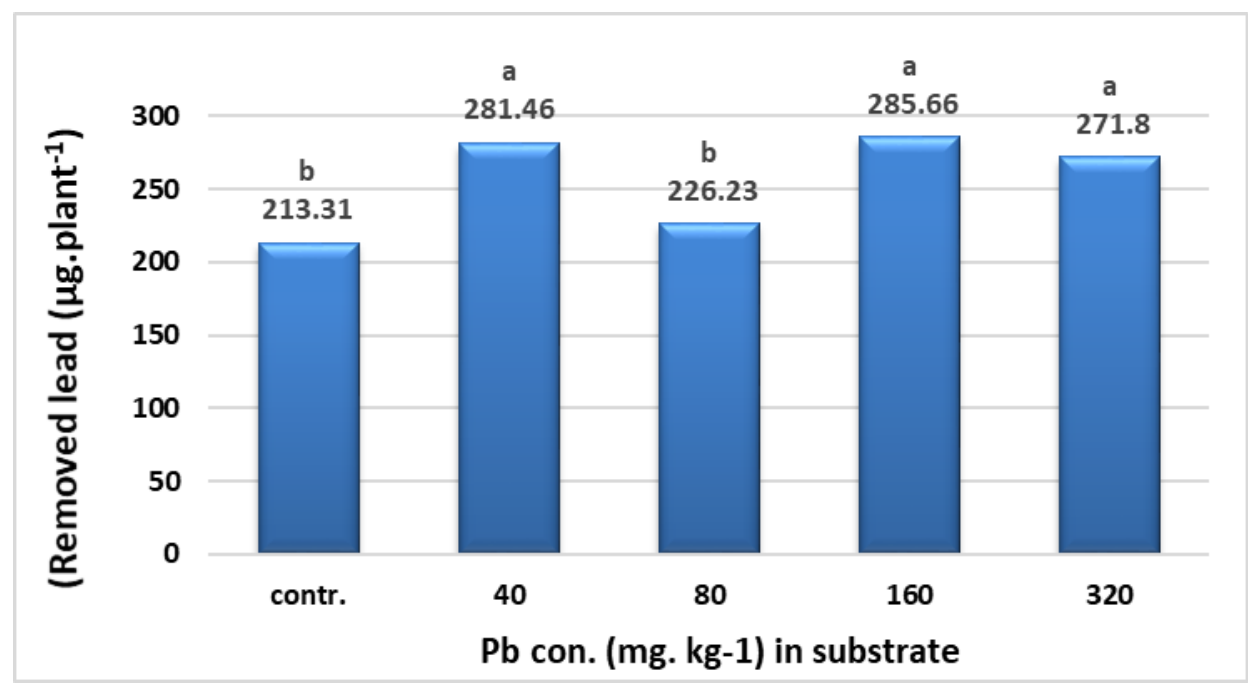

Fig. (1): Removed lead ( $\mu$ g. plant ${ }^{-1}$ ) by shoots of S. marianum L.

Values with same letter are not significantly different.

\section{CONCLUSIONS}

In conclusion, it is evident that this study has shown that $S$. marianum L. can be considered a hyperaccumulator plant because it was able to transport same amount of lead from roots to shoots (TF was more than one), therefore it is useful for phytoextraction of lead from polluted soils.

\section{REFERENCES}

- Ali H., M. Naseer, and M. A. Sajad (2012). Phytoremediation of heavy metals by Trifolium alexandrine. International Journal of Environmental Sciences, 2 (3): 1459 1469.

- Al-Rawi, K. M. and Khalafalla, A. (2000). Analysis of Experimental Agriculture Disgen. Dar Al-Kutub for Printing and Publishing. Mosul Univ. (In Arabic).

- Andrzejewska, J., T. Martnelli, and Sadowska, K. (2015). Silybum marianum: non-medical exploitation of species. Ann Appl Biol, 167:285-297.

- Angelova, V. (2013). Potential of some medicinal and aromatic plants for phytoremediation of contaminated with heavy metals soils. Proceeding of the XV Balkan Mineral Proceeding congress, Sozopo, Bulgaria, June 12-16: 1045-1048.

- Angelova, V. R., Perifanova-Nemska, M. N., Krustev, L. K., and Uzunova, G. P. (2018). Potential of silybum marianum L. for phytoremediation of soils contaminated with heavy metals. Ecology and Safety., vol. (12): 267-282.

- Awofolu, O. R. (2005). A survey of trace metals in vegetation, soil and lower animal along some selected major roads in metropolitan city of Lagos. Environmental Monitoring and Assessment, 105: 431-447.

- Blaylock, M., D. E. Salt, S. Dushenkov, O. Zakharova, C. Gussman, Y. Kapulnik, B. D. Ensley, and Raskin, I. (1997). Enhanced 
Accumulation of $\mathrm{Pb}$ in Indian Mustard by Soil-Applied Chelating Agents. Environ. Sci. Technol. 31: 860-865.

- Clemens, S. (2006). Toxic metal accumulation, responses to exposure and mechanisms of tolerance in plants. Biochimie, 88: 17071719.

- Del Rio-Celestino, M., Font, Rafael, MorenoRojas, R. and De Haro-Bailon, A. (2006). Uptake of lead and zinc by wild plants growing on contaminated soils.industrial Crops and Products, 24: 230-237.

- Duncan, D. B. (1955). Multiple Range and multiple F. tests. Biometrics, 11: 1-42.

- Evangelou, M. W. H., Ebel, M., and Schaeffer, A. (2007). Chelate assisted phytoextraction of heavy metals from soil. Effect, mechanism, toxicity, and fate of chelating agents. Chemosphere, 68: 989-1003.

- Fulekar, M.H., S., Anamika and Anwesha, M. B. (2009). Genetic engineering strategies for enhancing phytoremediation of heavy metals. African Journal of Biotechnology, 8 (4): 529-535.

- Gabos, M. B., C. A. Abreu, and Coscione, A. R. (2009). EDTA assisted phytorremediation of a $\mathrm{Pb}$ contaminated soil: metal leaching and uptake by jack beans. Sci. Agric. (Piracicaba, Braz.), 66(4): 506-514.

- Ghafor, Y., Mohammad, N. N., and Salh, D. M. (2014). Extraction and determination of chemicals ingredients from stems of Silybum marianum. Chemistry and Material Research, 6(4):26-32.

- Goswami, R., R. Thakur, and Sarma, K. P. (2010). Uptake of Lead from Aqueous Solution using Eichhornia crassipes: Effect on Chlorophyll Content and Photosynthetic Rate. International Journal of Chem Tech Research, 2 (3): 1702-1705.

- Habash D, m. Paul, M. A. J. Parry, A. J. Keys, and Lawlor, D. W. (1995). Increased capacity for photosynthesis in wheat grown at elevated $\mathrm{CO} 2$ : the relationship between electron transport and carbon metabolism. Planta 197: 482-489.

- Henry, J. R. (2000). An Overview of the Phytoremediation of Lead and Mercury. U.S. Environmental Protection Agency Office of Solid Waste and Emergency Response Technology Innovation office Washington, D.C.
- Kumar, P.B., V. Dushenkov, H. Motto, and Raskin, I. (1995). Phytoextraction: The use of plants to remove heavy metals from soils. Environmental Science and Technology, 29: 1232-1238.

- Meers, E., A. Ruttens, M. J. Hopgood, D. Samson, and Tack, F.M.G. (2005). Comparison of EDTA and EDDS as potential soil amendments for enhanced phytoextraction of heavy metals. Chemosphere, 58: 1011-1022.

- Mukhopadhyay, S., and Maiti, S. K. (2010). Phytoremediation of metal Mine waste. Applied Ecology and Environmental Research, 8(3): 207-222.

- Nas, F, S and Ali, M. (2018). The effect of lead on plants in terms of growing and biochemical parameters: a review. MOJ Ecology and Environmental Sciences, Volume 3(4).

- Paz-Alberto, A. M., G. C. Sigua, B. G. Baui and Prudente, J. A. (2007). Phytoextraction of Lead-Contaminated Soil Using Vetivergrass (Vetiveria zizanioides L.), Cogongrass (Imperata cylindrica L.) and Carabaograss (Paspalum conjugatum L.). Env Sci Pollut Res, 14 (7): 498 - 504.

- Pinho, S., and B. Ladeiro (2012). Phytotoxicity by Lead as HeavyMetal Focus on Oxidative Stress (Review Article. Journal of Botany, Article ID 369572: 1-10.

- Qu, J., C. Q. Lou1, X. Yuan, X. H. Wang, Q. Cong, and Wang, L. (2011). The effect of sodium hydrogen phosphate/citric acid mixtures on phytoremediation by alfalfa \& metals availability in soil. J. Soil Sci. Plant Nutr., 11(2): 85 - 95 .

- Sajad, M. A., M. S. Khan, H. Ali., and Nisa, Z. (2018). Lead phytoremediation potential of sixty-one plant species: An open field survey. Pure Appl. Biol. http://dx.doi.org/10.1904/bspab.2018.70020 $\underline{0}$.

- Sharma, P. and R.S. Dubey, (2005). Lead toxicity in plants. Braz. J. Plant Physiol., 17: 35-52.

- Suchkovaa, N., E. Darakasb, and Ganoulis, J. (2010). Phytoremediation as a prospective method for rehabilitation of areas contaminated by long-term sewage sludge storage: A Ukrainian-Greek case study. Ecological Engineering, 36: 373-378. 
- Tandon, H. (1999). Methods of analysis of soils, plants, water and fertilizers. Fertilisers Devolpment and Consulation, New Delhi India, pp.144.

- Tournas, V. H., C. Sapp, Trucksess, M. W.(2012). Occurrence of aflatoxins in milk thistle herbalsupplements.Food Additives and Contaminants, 29(6):994-999.

- Wianowska, D, and Wiśniewski, M. (2014). Simplified procedure of Silymarin extraction from Silybum marianum L. Gaertner. Journal of chromatographic science, 2015 (53): 366-372.

- National Academy of Science, (1972). Airborne lead in perspective. Washington, Dc.

- Mohamed, A. E., Rashed, M. N., and Mofty, A. (2003). Assesment of essential and toxic elements in some kinds of vegetable. Ecotoxicolo. And Environ. Saftey., 55: 251260.

- Zimdahl,R. L. and Koeppe, D. E. (1979). Uptake by plants. In lead in the environment. Bogges, W.R. Edi. CASTLE HOUSE PUBLICATIONLTD.

- Pulford I. D. and C. Watson (2003). Phytoremediation of heavy metalcontamined land by trees - a review. Environ Internat 29: 529-540.

ههلمزاناندنا رووهكى بو قورقوشم ز ئاخيّت ييس ب ريّكا قيفاري Si I ybummar i anumL.

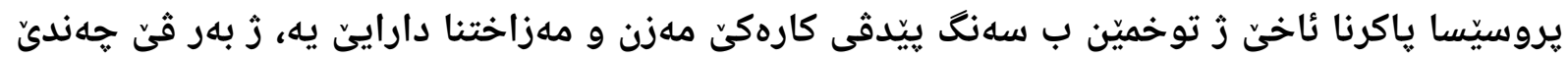

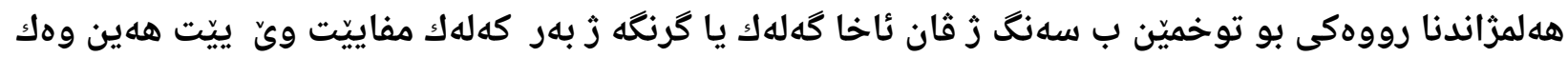

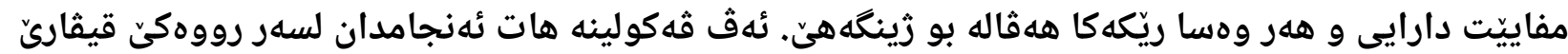
Silybum marianum L

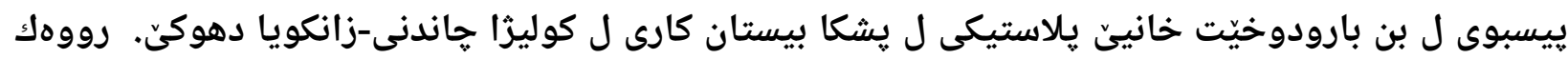

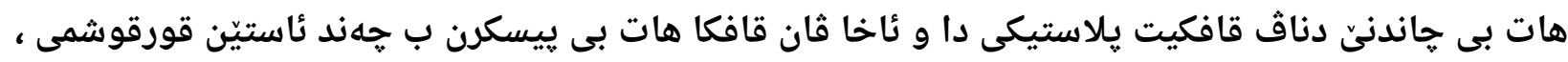

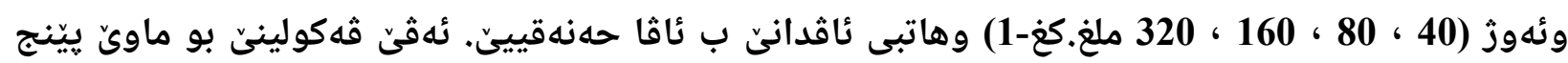

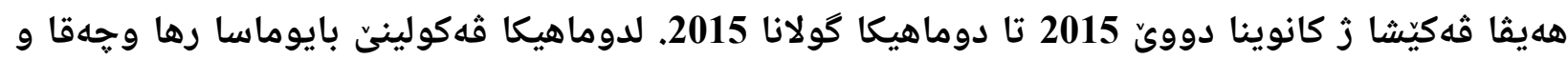

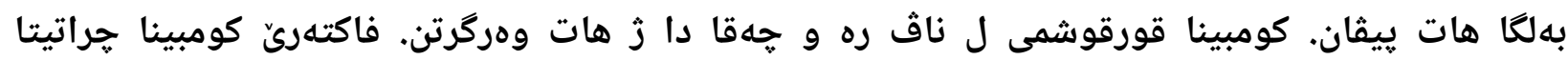

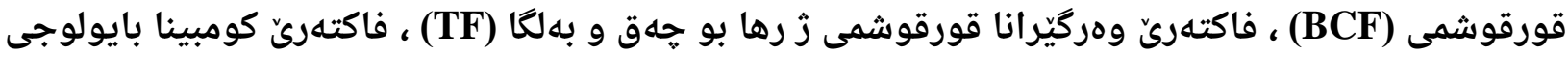

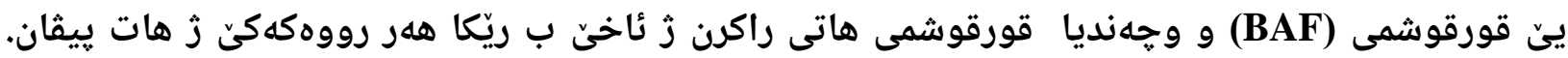
بايوماسا قيقاري كيّمبى دگهل زيدهبينا ريّزا قورقوشهمى دناث ئاخيّ دا و كيّمترين بايوماس يا وان رووهكا بى

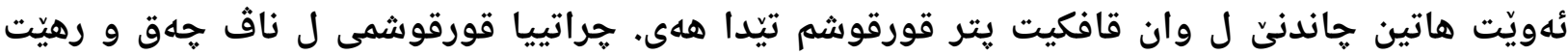

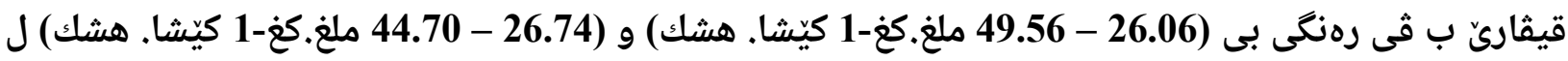

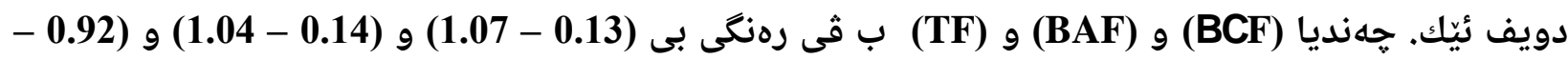

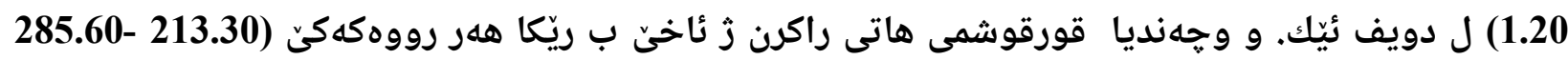

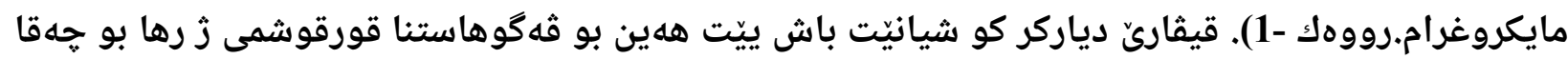

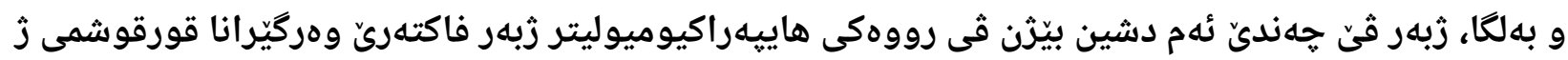
رها بو جهاق و بهلكا يتر بـ زَئيكىّ. 
Si I ybummari anumL. الاستخلاص الخضري للرصاص من الترب الملوثة بواسطة الكلغان

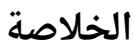

ان عملية أستصلاح الترب الملوثة بالعناصرالثقيلة تتطلب جهد كبير وتكاليف اقتصادية هائلة، لذلك فأن الذاندان

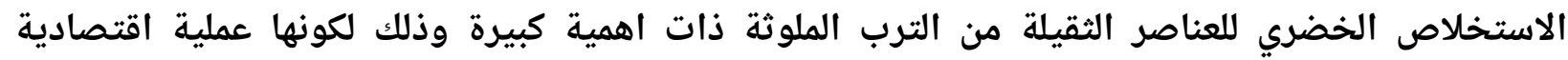

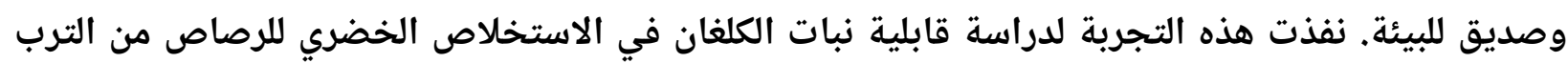

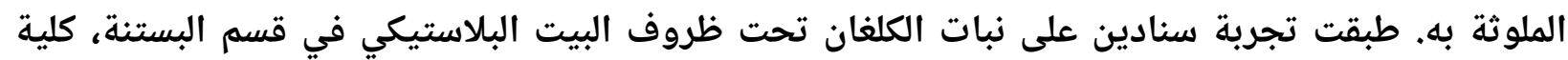

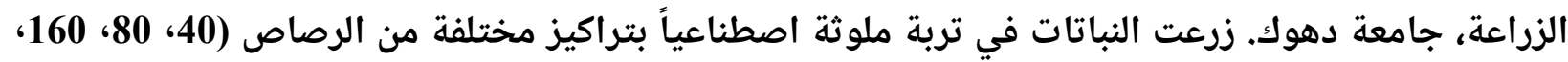

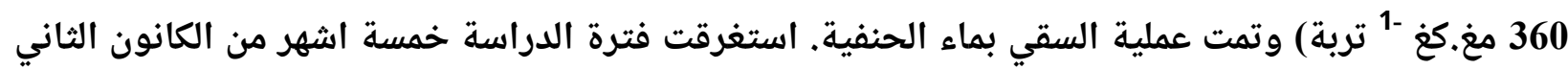

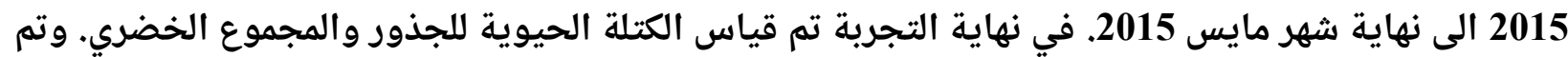

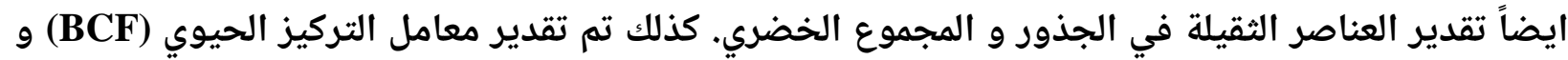

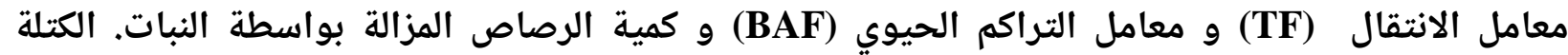

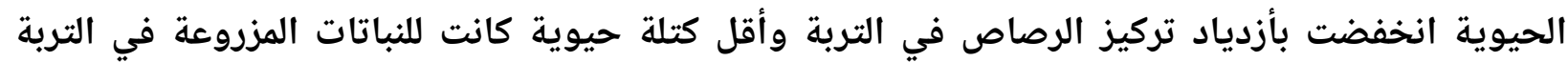

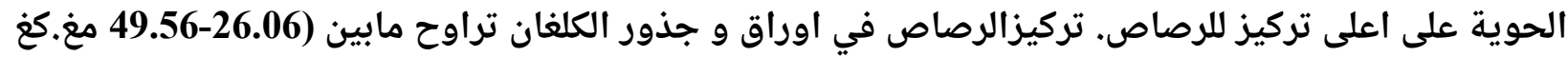

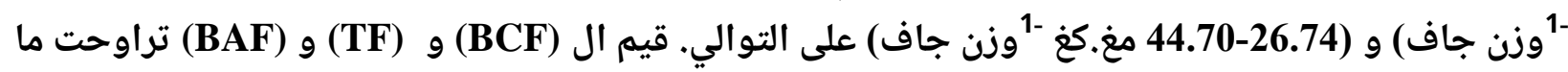

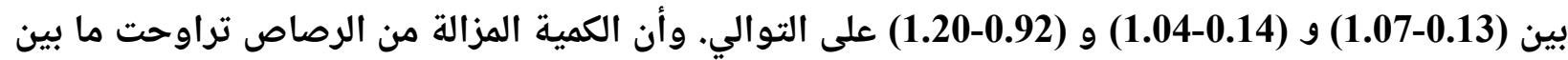

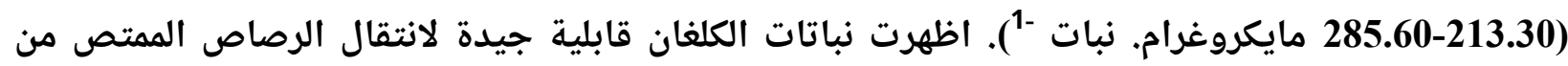

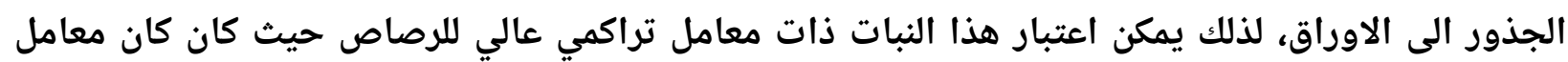
الانتقال للرصاص اكبر من واحد. 